\title{
Identification of Naturally Processed T Cell Epitopes from Glutamic Acid Decarboxylase Presented in the Context of HLA-DR Alleles by T Lymphocytes of Recent Onset IDDM Patients
}

\author{
Josef Endl, ${ }^{\star}$ Heike Otto, ${ }^{\ddagger}$ Günther Jung, ${ }^{\ddagger}$ Barbara Dreisbusch, ${ }^{*}$ Frederic Donie, ${ }^{\star}$ Peter Stahl, ${ }^{\star}$ Rudi Elbracht, ${ }^{\S}$ Gerd Schmitz, $\$$ \\ Edgar Meinl," Michael Hummel," Anette-G. Ziegler," Rudolf Wank, ${ }^{* \star}$ and Dolores J. Schendel** \\ *Boehringer Mannheim Research Center, D-82377 Penzberg; ${ }^{\ddagger}$ Institute of Organic Chemistry, University of Tübingen, D-72076 Tübingen; \\ ${ }^{\S}$ Institute for Clinical Chemistry, University of Regensburg, D-93053 Regensburg; "Institute for Clinical and Molecular Virology, \\ University of Erlangen-Nürnberg, D-91054 Erlangen; "Diabetes Research Institute, Academic Hospital München-Schwabing, D-80804 \\ Munich; and **Institute of Immunology, University of Munich, D-80336 Munich, Germany
}

\begin{abstract}
Glutamic acid decarboxylase (GAD) has been defined as a major target antigen in insulin-dependent diabetes mellitus (IDDM). To identify the molecular ligands triggering a $T$ cell response to GAD, a panel of human GAD65-specific T lymphocyte lines was generated from peripheral blood of three recent onset IDDM patients. All lines derived from a patient expressing the high-risk-conferring HLA-DR*0301/ *0401 haplotypes recognized a single epitope localized between amino acid positions 270 and 283 of GAD65, a stretch that is located in close proximity to the homology region shared with Coxsackie virus P2-C protein. All lines with this specificity were restricted to the DRA, B1*0401 product of the DR4 haplotype. Analysis of the GAD-specific T cell response in a second patient homozygous for DR4 haplotypes demonstrated that the same DRA, B1*0401 allele selected $T$ cells specific for a different determinant. The $T$ cell response profile in a third patient showed that DR*1501/ *1601-encoding haplotypes could present at least three different epitopes to GAD65-specific T lymphocytes. One of these epitopes was presented by a DR allele associated with the resistance-conferring DRB1*1501 haplotype. GAD-specific $\mathrm{T}$ cell lines could not be isolated from HLA class IImatched normal individuals. Our data reveal that $(a)$ the $\mathrm{T}$ cell response to GAD65 is quite heterogenous in recent onset IDDM patients; (b) HLA-DR, not DQ, seems to be the principal restriction element used by $T$ cells present at the onset of the disease; and (c) T cells responding to epitopes containing identical sequences to Coxsackie virus $\mathrm{P} 2-\mathrm{C}$ protein were not detected. (J. Clin. Invest. 1997. 99:2405-2415.) Key words: T cell epitopes - glutamic acid decarboxylase • autoimmunity $\cdot$ peptide autoantigens $\cdot$ Coxsackie virus
\end{abstract}

Address correspondence to Dr. Josef Endl, Boehringer Mannheim Research Center, Nonnenwald 2, D-82377 Penzberg, Germany. Phone: 49-8856-602788; FAX: 49-8856-603068; E-mail: josef_endl@bmg.cor ange.com

Received for publication 18 December 1996 and accepted in revised form 3 March 1997.

J. Clin. Invest.

(c) The American Society for Clinical Investigation, Inc.

0021-9738/97/05/2405/11 \$2.00

Volume 99, Number 10, May 1997, 2405-2415

\section{Introduction}

Insulin-dependent diabetes mellitus (IDDM) ${ }^{1}$ is an organ-specific autoimmune disease characterized by lymphocytic infiltration of the pancreatic islets of Langerhans, and by complete destruction of pancreatic beta cells (1). This disease process occurs over long periods of time, often years, eventually reaching a stage where insufficient beta cells are available for insulin production. Susceptibility to IDDM is genetically controlled, and in humans particular alleles of the major histocompatibility complex (MHC) DR and DQ loci confer high disease risk (2-6). During normal immune responses, molecules encoded by DR and DQ genes bind and present peptide fragments of protein antigens to lymphocytes of the CD4 subset. These class II molecules could play a pivotal role in the development of IDDM through presentation of islet cell-specific peptides to autoimmune $\mathrm{CD}^{+}{ }^{+} \mathrm{T}$ lymphocytes. Several beta cell-specific proteins have been identified as disease targets using patient autoantibodies; more than $80 \%$ of prediabetics and most recent onset diabetics have autoantibodies directed against the enzyme glutamic acid decarboxylase (GAD) (7). The destruction of pancreatic beta cells, however, is thought to be mediated by T cells (8). Peripheral blood mononuclear cells (PBL) from approximately one-half of new-onset IDDM patients were found to respond to GAD (9-11). Recently, using bulk culture stimulation assays with synthetic peptides of GAD, lymphocyte proliferation was detected in patients as well as in normal persons $(12,13)$, albeit in the majority of subjects the stimulation indices were quite low. Cytotoxic T cells recognizing an HLA-A2-restricted peptide of GAD have been found in prediabetics and patients with recent onset disease, but not in normal control donors (14). An increased disease risk associated with HLA-A2 has not been found. To date, the full characterization of naturally processed $\mathrm{T}$ cell epitopes of GAD65, including definition of the minimal peptides and identification of the class II molecules required for peptide presentation to $\mathrm{CD}^{+} \mathrm{T}$ cells, has not been available.

Our approach to study the immune response to GAD is based on the isolation of antigen-specific T cell lines (TCL) from recent onset IDDM patients first by priming with native protein, and, in a second step, by screening the TCL with a set of overlapping 20-mer peptides, thereby allowing a detailed characterization to be made of the molecular elements in-

1. Abbreviations used in this paper: APC, antigen-presenting cells; hGAD65, recombinant human $65 \mathrm{kD}$ glutamic acid decarboxylase; IDDM, insulin-dependent diabetes mellitus; pGAD, glutamic acid decarboxylase isolated from porcine brain; TCL, T cell lines. 
volved in antigen recognition. We have chosen for our study three recent onset IDDM patients with HLA class II genotypes conferring different risk potentials. In addition, we included two healthy controls, completely or partially matched for high-risk alleles with the patients. This strategy led to the identification of a series of epitopes of GAD which are exclusively presented by $\mathrm{DR}$ molecules to $\mathrm{CD}^{+} \mathrm{T}$ cells isolated from IDDM patients. Contribution of DQ molecules in the antigen-presenting process could be excluded.

\section{Methods}

Patients and healthy donors. All patients were hospitalized at the Third Medical Department of the Academic Hospital MünchenSchwabing. Type I diabetes was defined on the basis of a clinical diagnosis. All of these patients had ketone bodies in urine at diagnosis, had body mass indices below 25 , and have been dependent on insulin since diagnosis. Further clinical features of the patients as well as of the healthy volunteers are given in Table I.

Antigens. Porcine GAD (pGAD) was isolated from cerebellum according to the method of Wu et al. (15). Recombinant human $65 \mathrm{kD}$ GAD (hGAD65), expressed in the Baculovirus system, was purchased from Synectics (Stockholm, Sweden). The endotoxin content of this preparation was below $0.3 \mathrm{EU} / \mathrm{ml}$ (determined in the Limulus lysate assay). For determination of peptide specificity, a set of 5720 mer oligopeptides with overlaps of 10 amino acids spanning the entire protein and one $\mathrm{NH}_{2}$-terminal 15 -mer peptide were used. Synthesis was carried out on Fmoc-amino acid-Wang resin using a robot system for simultaneous multiple solid phase peptide synthesis (SMPS 350; Zinsser Analytic, Frankfurt, Germany). The purity of peptides was checked by reversed-phase HPLC. Identity of peptides was confirmed by electrospray mass spectrometry (API III triple quadrupole ion-spray mass spectrometer; Sciex Inc., Ontario, Canada). If necessary, peptides were further purified by preparative HPLC to a purity of at least $95 \%$.

Generation of TCL. All cell cultures were set up in RPMI medium containing $5 \%$ human serum (pooled from at least six male donors). TCL were generated from peripheral blood of newly diagnosed IDDM patients essentially as previously described (16), using highly purified pGAD $(5 \mu \mathrm{g} / \mathrm{ml})$ or hGAD65 as the stimulating antigen. For primary stimulation, about 200 microcultures, each containing 1.0-1.5 $\times 10^{5}$ PBL per well were set up for every subject. After a stimulation period of 6-7 d with antigen alone, IL-2 was added in a final concentration of $15 \mathrm{U} / \mathrm{ml}$. After at least three rounds of weekly restimulation with autologous antigen-presenting cells (APC), PBL from HLA-class II fully matched donors were used as APC for restimulation of the TCL with native antigen. Molecular HLA class II typing of the patients and allogeneic donor APC was performed with sequence-specific oligonucleotides after DNA amplification with HLADRB1-, -DQA1- and DQB1-specific primers, as used in the 11th International Histocompatibility Workshop (17).

Proliferation assay. For proliferation assays with established $\mathrm{T}$ cell lines, cultures were set up in round-bottomed 96-well culture vessels, using $6 \times 10^{3} \mathrm{~T}$ cells from each TCL and $1 \times 10^{5}$ irradiated $(40$ Gy) autologous or HLA class II fully matched donor PBL as APC. Native pGAD or hGAD65 was added in culture in a final concentration of $5 \mu \mathrm{g} / \mathrm{ml}$. For determination of peptide specificity, the TCL were first screened with pools consisting of four to five peptides, each in a final concentration of $10 \mu \mathrm{g} / \mathrm{ml}$. The TCL were tested for proliferation against individual peptides in a final concentration of $5 \mu \mathrm{M}$. All cultures were incubated for $72 \mathrm{~h}$ at $37^{\circ} \mathrm{C}$ with $5 \% \mathrm{CO}_{2}$, then pulsed with $1 \mu \mathrm{Ci}$ of $\left[{ }^{3} \mathrm{H}\right]$ thymidine, and incorporated radioactivity was collected on glass fiber filters and measured by direct beta counting.

To identify the class II restriction element used for presentation of the epitopes, the TCL were probed with a panel of APC matched for particular DR and/or DQ alleles with the patient. The APC $(2 \times$ $10^{5}$ cells/well) were first pulsed with antigenic peptides (100 nM-2.5 $\mu \mathrm{M})$ for $3 \mathrm{~h}$ at $37^{\circ} \mathrm{C}$, irradiated ( $40 \mathrm{~Gy}$ ), and then washed three times to remove any excess unbound peptide. Further conditions for the proliferation assays were the same as described above for established T cell lines. Data are presented as SI calculated as follows: mean cpm of response to peptide divided by mean cpm with medium only. SI values greater than three were considered positive.

Blocking experiments. The isotype of class II molecules recognized by each TCL was determined by antibody blocking experiments. The APC $\left(1 \times 10^{5}\right.$ cells per well $)$ were first incubated with the various $\mathrm{mAb}$ in final concentrations of $5-10 \mu \mathrm{g} / \mathrm{ml}$ for $30 \mathrm{~min}$ at $37^{\circ} \mathrm{C}$. Peptides were then added in a final concentration of $100 \mathrm{nM}-2.5 \mu \mathrm{M}$, and after $3 \mathrm{~h}$ at $37^{\circ} \mathrm{C}$, the APC were irradiated (40 Gy). Further conditions for the proliferation assay were the same as described above. Percent reactivity was calculated as follows: $100 \times($ mean cpm of response to peptide in the presence of $\mathrm{mAb}$ minus mean $\mathrm{cpm}$ of response with medium containing only $\mathrm{mAb}) /($ mean $\mathrm{cpm}$ of response to peptide minus mean cpm of response with medium only). $100 \%$ reactivity is defined as the response to peptide minus the response of cells in medium alone.

Monoclonal antibodies recognizing either framework determinants on DR- (mAb L243) and DQ- (mAb SPVL3) heterodimers, or $m A b$ specifically recognizing the two DQ alleles (DQ2 and DQ8) of the autologous APC (mAb C1 and 7bF4, respectively) were used (18). The class I specific $\mathrm{mAb} \mathrm{W} 6 / 32$ was used as a control. The $\mathrm{mAb}$ were used either $(a)$ in the form of purified IgG prepared by chromatography on protein A-Sepharose from culture supernatants of hybridoma cell lines obtained from the American Type Culture Collection (Rockville, MD) (W6/32, L243), (b) purchased from Immunotech, France (SPVL3), or (c) used as diluted culture supernatants of local hybridoma cell lines $(\mathrm{C} 1$ and $7 \mathrm{bF} 4)$ in final concentrations of $5-10 \mu \mathrm{g} / \mathrm{ml}$.

Beta cell antibody determination. Sera were screened for conventional islet cell antibody immunoglobulin G (ICA-IgG) by means of indirect immunofluorescence on cryostat sections of blood group 0 human pancreas, and for insulin autoantibodies (IAA) using a competitive fluid phase radiobinding assay (19). GADA were analyzed by radioligand binding assays (20). Sera were regarded as positive if antibody levels were above the 99th percentile of normal controls (cut off at $13 \mathrm{U}$ for GADA).

Analysis of cytokine production. T cell lines $\left(1-2.5 \times 10^{4}\right.$ cells/ well) were stimulated by corresponding autoreactive peptides $(5 \mu \mathrm{M})$ in $100-\mu \mathrm{l}$ cell culture medium for $72 \mathrm{~h}$, and the supernatants were evaluated for cytokine production by commercial solid phase immunoenzymatic assays: interleukin-2 (IL-2) (Boehringer Mannheim Corp., Indianpolis, IN); interleukin-4 (IL-4), interleukin-6 (IL-6), and interferon-gamma (IFN $\gamma$ ) (Biosource International, Camarillo, TX). Minimal detection levels for the various cytokines were: $5 \mathrm{pg} / \mathrm{ml}$ for IL-2, $20 \mathrm{pg} / \mathrm{ml}$ for IL-4, $2 \mathrm{pg} / \mathrm{ml}$ for IL-6, and $10 \mathrm{pg} / \mathrm{ml}$ for IFN $\gamma$.

\section{Results}

Peptide specificities of $h G A D 65$-reactive TCL isolated from IDDM patients expressing high risk $H L A$-alleles. To identify the ligands activating autoreactive T cells, we established longterm $\mathrm{T}$ cell lines from peripheral blood of recent onset IDDM patients. To generate such lines, we used a series of microcultures with limiting numbers of cells, thus allowing us to isolate from each donor a number of independently derived peptidespecific T cell lines.

HLA class II genotyping of the first patient (patient 6), whom we selected for the isolation of hGAD65-specific TCL, showed that he expressed the high-risk DR3/4-DQ2/8 genotype (Table I). We isolated four TCL $(6 / 4,6 / 7,6 / 8$, and 6/10) from this patient by repeated stimulation of $\mathrm{PBL}$ with native porcine-derived GAD ( $\mathrm{pGAD}$ ). A strong bias for selection of $T$ cells specific for porcine epitopes was not expected given the high homology (96\%) between pig and human GAD (21). In a 
72-h proliferation assay, these TCL showed significant responses to pGAD as well as to hGAD65, albeit of a lower magnitude in two of the four lines (Fig. 1, $A 1-A 4$ ). These results demonstrated that the epitopes recognized by the four TCL are present in the corresponding human enzyme isoform.
To define the immunogenic determinants seen by these TCL, the epitopes were tested with overlapping 20-mer peptides spanning the whole hGAD65 protein. Stimulation with peptide pools consisting of four to five peptides revealed that all TCL proliferated best to pool 11; three lines responded to pool

TCL 6/4
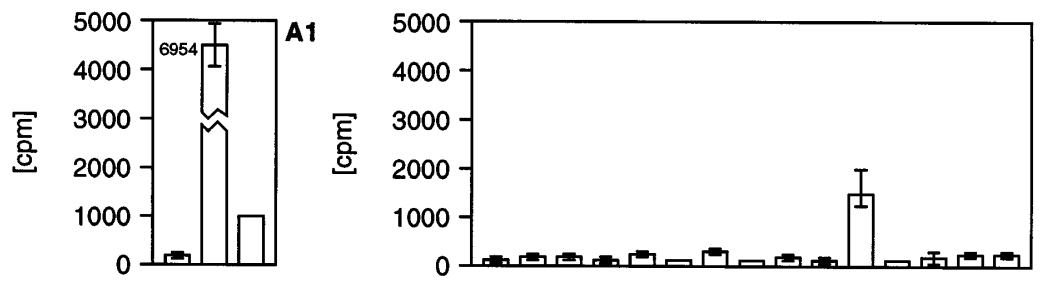

B1

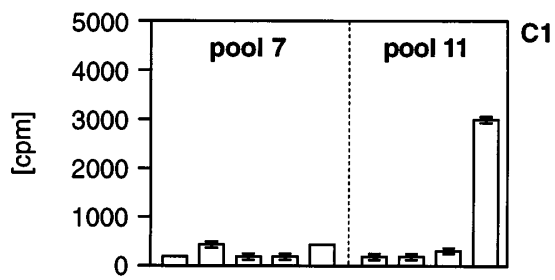

TCL 6/7

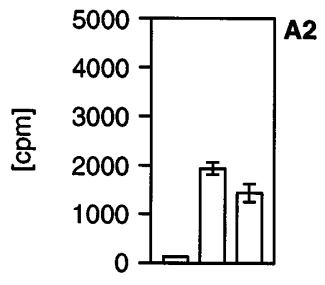

A2

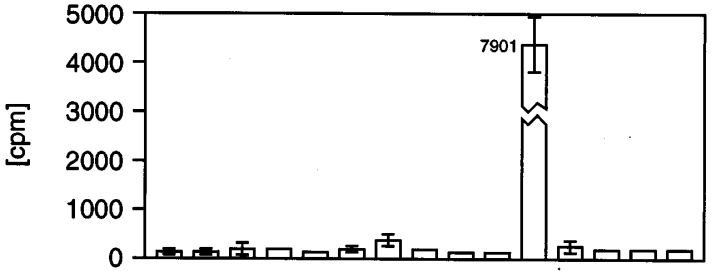

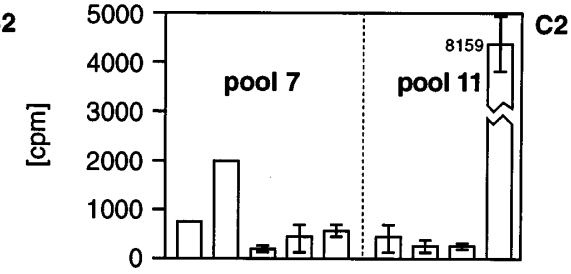

TCL 6/8

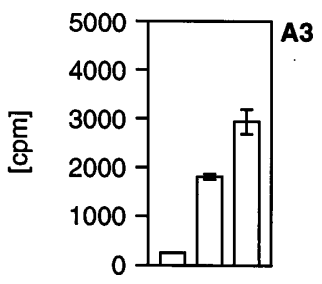

$$
\text { 릉 }
$$
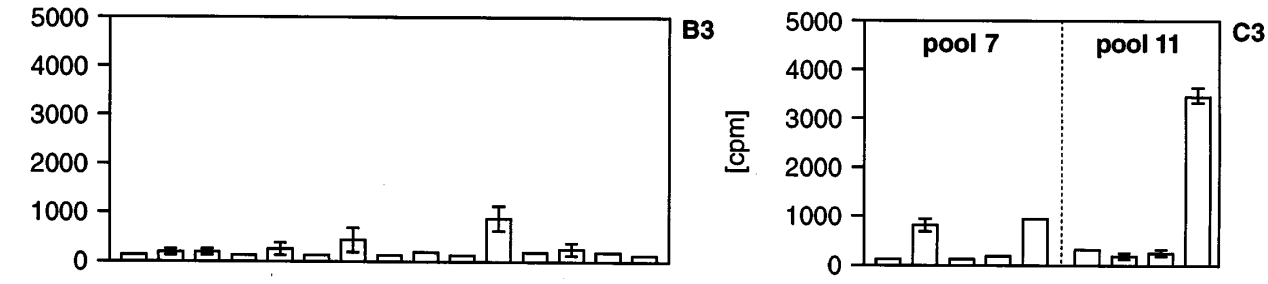

\section{TCL 6/10}
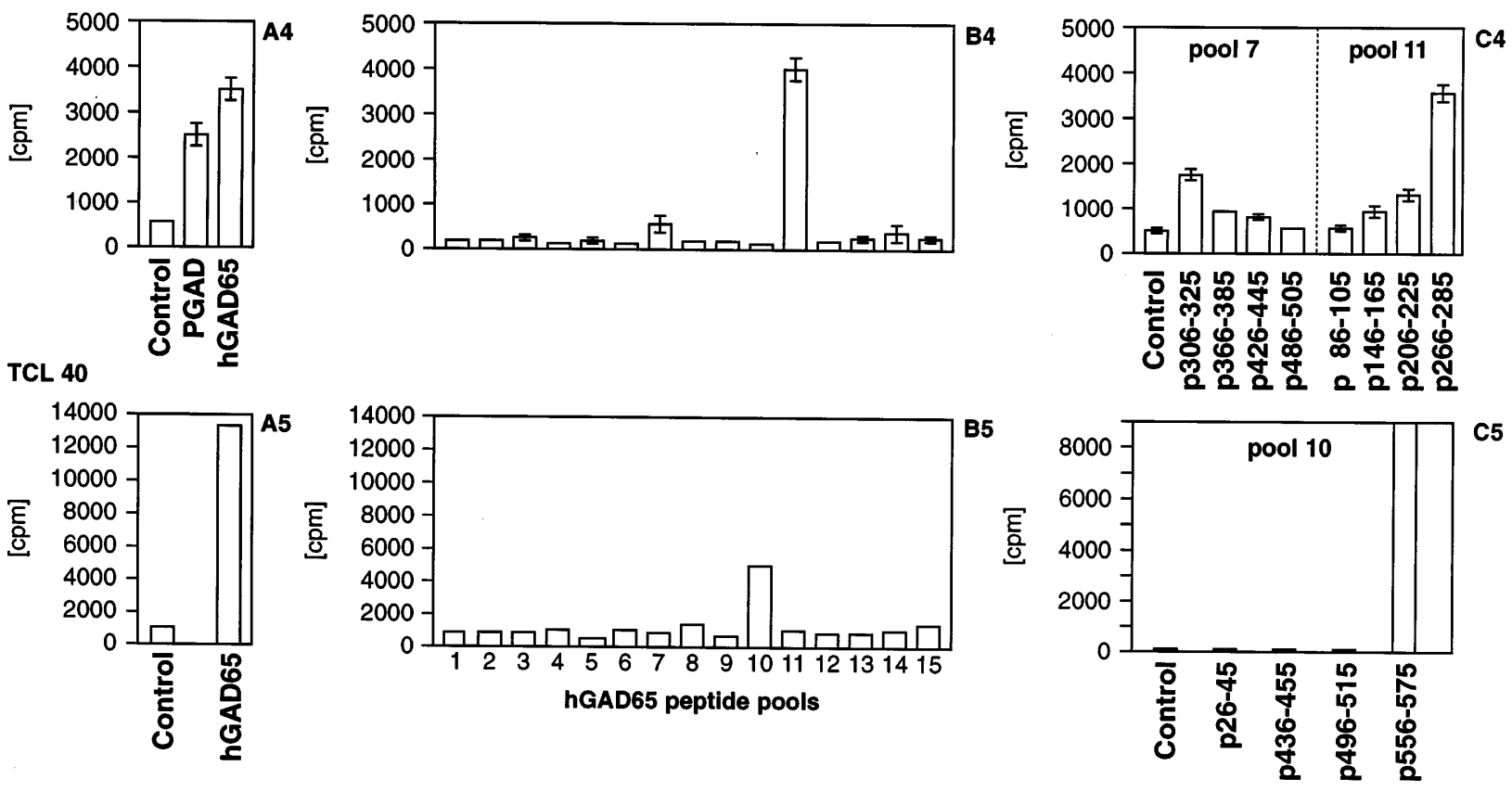

Figure 1. Proliferative responses of TCL isolated from high-risk IDDM patients 6 and 40 with GAD and a set of overlapping 20-mer oligopeptides derived from hGAD65. ( $A 1-A 5)$ TCL generated from recent onset IDDM patients were tested for proliferation against native pGAD (5 $\mu \mathrm{g} / \mathrm{ml})$ and hGAD65 $(5 \mu \mathrm{g} / \mathrm{ml})$. TCL cultured in medium without antigen served as the control for background proliferation. (B1-B5) TCL responses with pools of peptides derived from hGAD65. (C1-C5) The TCL were tested for proliferation against individual peptides which were included in individual peptide pools. Each data point represents the mean of duplicates \pm SEM. No SEM is given in cases where deviations from the mean are too low to be depicted. 
Table I. Characteristics of the IDDM Patients and Healthy Controls

\begin{tabular}{|c|c|c|c|c|c|c|c|c|}
\hline \multirow[b]{2}{*}{ Subject } & \multirow[b]{2}{*}{ Sex } & \multirow[b]{2}{*}{ Age I } & \multirow[b]{2}{*}{ Duration } & \multirow[b]{2}{*}{$\begin{array}{c}\text { ICA } \\
\text { JDFU }\end{array}$} & \multirow[b]{2}{*}{ GADA } & \multicolumn{3}{|c|}{ HLA class II alleles } \\
\hline & & & & & & DRB1* & DQA1* & DQB1* \\
\hline & & $y r$ & $d^{\ddagger}$ & & $U$ & & & \\
\hline \multicolumn{9}{|l|}{ Patients } \\
\hline 6 & $\mathrm{M}$ & 35 & 2 & 320 & 93 & 0301/0401 & 0501/0301 & 0201/0302 \\
\hline 40 & $\mathrm{~F}$ & 54 & 7 & 20 & 71 & 0401/0401 & 0301/0301 & $0302 / 0302$ \\
\hline 24 & $\mathrm{~F}$ & 43 & 2 & 0 & 3 & $1501 / 1601$ & 0102/0102 & $0602 / 0502$ \\
\hline \multicolumn{9}{|l|}{ Controls } \\
\hline KP3 & M & 33 & - & NT & 0 & 0301/0401 & 0501/0301 & 0201/0302 \\
\hline KP71 & $\mathrm{F}$ & 27 & - & NT & 0 & 0301/0401 & 0501/0301 & 0301/0301 \\
\hline
\end{tabular}

${ }^{\ddagger}$ Days after onset when PBL were obtained. $N T$, not tested.

7 to a much lesser degree (Fig. 1, B1-B4). Subsequent testing with the individual peptides showed that all TCL reacted with at least a sixfold response above background to peptide p266285 of pool 11 (Fig. 1, C1-C4). The minor response to peptide p306-325 of pool 7 was lost during further culture of the TCL in vitro, whereas the response to p266-285 gradually increased during further restimulation cycles. An identical response pattern was observed with an additional line, TCL 6/9 (data not shown).

All the previous analyses were carried out using $\mathrm{T}$ cells from IDDM patient 6 . To test if the immunodominant epitope of patient 6 was reactive in a second patient who shared the DR4/Dw4 haplotype, we established microcultures from another patient (patient 40, see Table I). As demonstrated in Fig. 1, A5, a hGAD65-specific TCL could be isolated from this patient. Testing the peptide pools revealed that reactivity was directed to pool 10 (Fig. 1, B5). Further analysis identified a different reactive 20-mer peptide, p556-575 (Fig. 1, C5), which is located at the $\mathrm{COOH}$-terminal end of hGAD65. We consider this an indication that the GAD-specific T cell response in individual patients can be heterogenous, even when they have common MHC haplotypes.

We also tried to generate GAD-specific TCL by applying the same method to PBL isolated from two healthy volunteers. One of these control subjects had completely identical HLA class II alleles to patient 6 (see Table I). Two independent attempts were made using the same number of microcultures (about 200) for primary stimulations as used for patient 6. No proliferative responses could be observed in any of the microcultures. We also failed to isolate autoreactive TCL by applying the same method to a second control person, who expressed high risk DRB1*0301/0401 alleles in combination with a protective DQB1*0301 allele.

Fine mapping of the immunodominant epitope identified in patient 6 . The oligo-peptide p266-285, recognized by all five TCL isolated from patient 6, maps to the middle region of hGAD65 in immediate proximity to a stretch of six amino acids duplicated in the $\mathrm{P} 2-\mathrm{C}$ protein of Coxsackie virus $(22,23)$. One model for the pathogenesis of IDDM proposes that Coxsackie virus-specific immune cells cause beta cell destruction because of this molecular mimicry with $\operatorname{GAD} 65(24,25)$. Since the borders of oligopeptides were chosen arbitrarily, it could not be excluded that the optimal epitope might extend to include adjacent $\mathrm{NH}_{2}$ - or $\mathrm{COOH}$-terminal residues. Synthetic peptides clustered around this region were next tested for their ability to induce TCL proliferation (Fig. $2 A$ ). The 20-mer peptides encompassing three or six amino acid shifts, respectively, towards the $\mathrm{COOH}$ terminus, still induced proliferation, whereas the peptide covering a six-amino acid shift towards the $\mathrm{NH}_{2}$ terminus did not activate the TCL. Therefore, the activating determinant for these TCL was located outside the region duplicated in $\mathrm{P} 2-\mathrm{C}$ protein. The peptide, however, does encompass a region of homology with the $\mathrm{P} 2-\mathrm{C}$ protein.

A set of truncated peptides was then used to identify the minimal region required to activate these TCL. Truncation at the $\mathrm{COOH}$ terminus (Fig. $2 \mathrm{~B}$ ) was tolerated as long as His at position 282 and Phe at position 283 were present in the stimulatory peptide. At the $\mathrm{NH}_{2}$ terminus residues 270 (Leu) and 271 (Pro) were obligatory for stimulation of TCL 6/4 and 6/8, whereas TCL 6/7 and 6/10 tolerated a truncation of these two $\mathrm{NH}_{2}$-terminal residues without a substantial loss of stimulation. Thus, there seems to exist a microheterogeneity with respect to affinity and/or fine specificity within the four lines. The minimal sequence recognized by all four TCL spanned a sequence of 14 amino acids (270-283) of hGAD65.

$H L A$-restriction of TCL derived from IDDM patients with high-risk HLA alleles. Phenotypic characterization with $\mathrm{mAb}$ specific for different lymphocyte subsets demonstrated that all lines isolated from patients 6 and 40 were comprised predominantly $(>95 \%)$ of $\mathrm{CD}^{+}{ }^{+} \mathrm{T}$ lymphocytes (data not shown). This phenotype, and the strong proliferation induced with exogenous peptide, indicated that the TCL would recognize peptide in association with MHC class II molecules. Inhibition studies were performed using $\mathrm{mAb}$ specific for DR and DQ molecules to determine which class II isotype was involved in peptide presentation; a class I-specific reagent was included as a control (Fig. $3 \mathrm{~A}$ ). Proliferation of all TCL was almost completely abrogated in the presence of the DR-specific $\mathrm{mAb}$ L243, whereas little or no inhibition was observed using the class I-specific $\mathrm{mAb}$ and a DQ-specific $\mathrm{mAb}$ that binds to a determinant common to all DQ molecules. The same kind of inhibition studies performed with the TCL isolated from PBL of patient 40 revealed that peptide presentation was significantly inhibited only with the DR-specific antibody (Fig. $3 \mathrm{~B}$ ). To exclude nonspecific inhibition by the anti-DR $\mathrm{mAb}$, a control experiment was performed using a class I restricted cytotoxic $\mathrm{T}$ cell line; only mAb W6/32 was inhibitory, whereas mAb L243 did not show any inhibition (data not shown). Taken together, these blocking studies indicated that oligopeptides p266-285 and p556-575 were presented to the TCL by DR molecules.

To identify the DR molecules used for peptide presentation, proliferation assays were performed using a panel of APC derived from donors who were completely or partially matched for the DR and DQ alleles of the patient. All APC with DRB1*0401 alleles stimulated the TCL generated from patient 6 in the presence of the minimal epitope p270-283 (Table II). The most conclusive result was revealed using cells of KP103: replacement of only the DRB1*0401 allele by the closely related DRB1*0404 allele resulted in complete loss of stimulation by $\mathrm{p} 270-283$. This analysis excluded any contribution of DQ molecules to antigen presentation. Furthermore, another subtype (DRB1*0402) that is closely related to DRB1*0401, and also associated with IDDM risk, was ineffective in peptide presentation to TCL from patient 6 , as were other DR susceptibility alleles, including subtypes of DR1, 


\section{0 - 279 PEVKEKGMAALPRLIAFTSE}

$268-285$

AALPRLIAFTSEHSHFSL

$268-283$

AALPRLIAFTSEHSHF

$268-281$

AALPRLIAFTSEHS

$268-279$

AALPRLIAFTSE

$266-279$ GMAALPRLIAFTSE

$266-277$

GMAALPRLIAFT

$270-287$

LPRLIAFTSEHSHFSLKK

$272-285$

RLIAFTSEHSHFSL

$270-283$

LPRLIAFTSEHSHF

$270-281$

LPRLIAFTSEHS

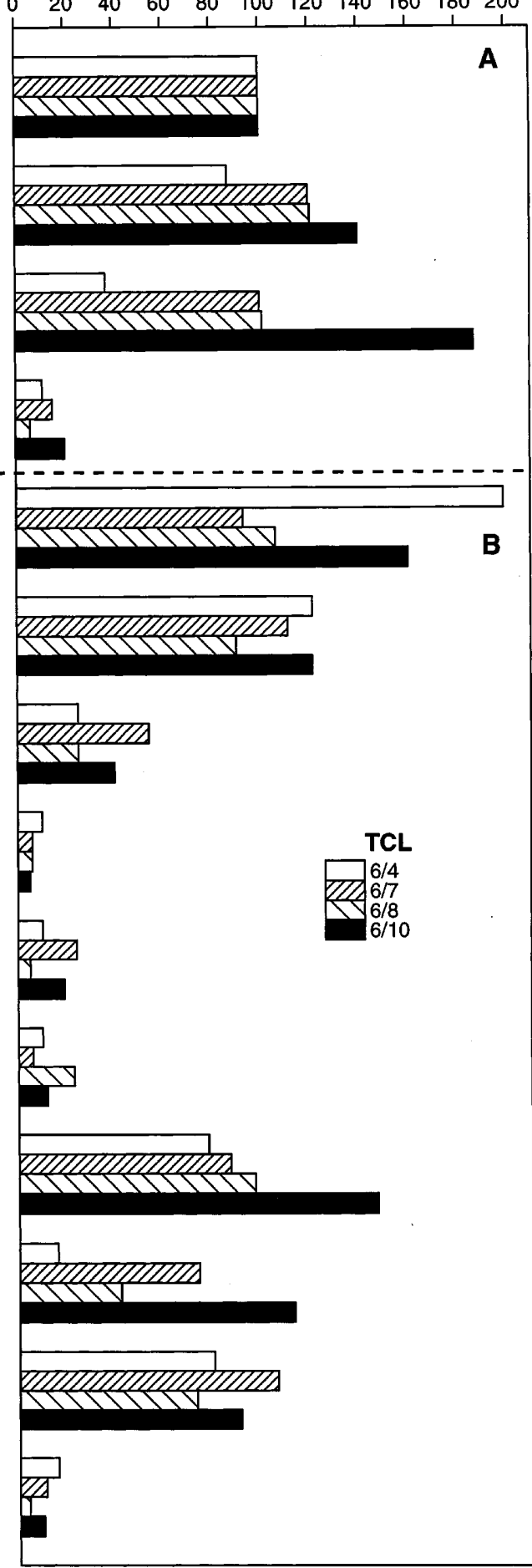

Figure 2. Minimization analysis of the epitope that activates the TCL obtained from patient 6. $(A)$ A series of variant peptides clustered around the immunogenic 20-mer peptide (identified in the initial mapping studies) was tested for stimulatory capacity of all four TCL. Proliferation was retained with 20-mer peptides shifted three (p269-288) or six (p272-291) amino acids towards the COOH terminus. Only TCL 6/4 showed a significant reduction in proliferation using peptide p272-291. In contrast, stimulation of all TCL was completely abrogated with a 20-mer peptide (p260-279), encompassing a shift towards the $\mathrm{NH}_{2}$ terminus to include the region duplicated in Coxsackie virus $\mathrm{P} 2-\mathrm{C}$ protein (box). (B) Further truncations at the $\mathrm{COOH}$ terminus and $\mathrm{NH}_{2}$ terminus revealed a 14-mer (p270-283) sequence as the minimal peptide capable of activating all four of the TCL. The anchor positions described to be essential for binding to DRB1*0401 are given in bold. 
TCL 6/4

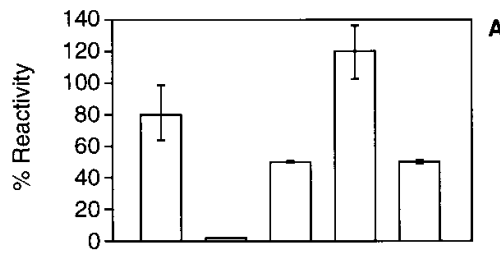

TCL $6 / 7$

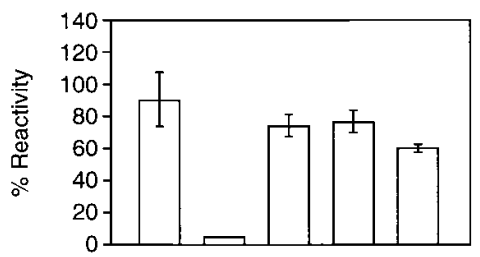

TCL 6/8

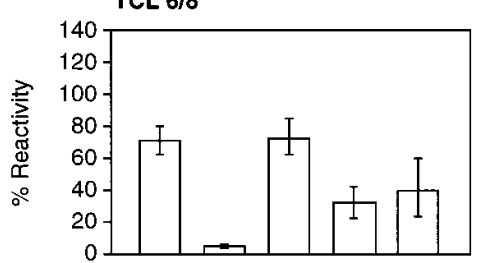

TCL $6 / 10$

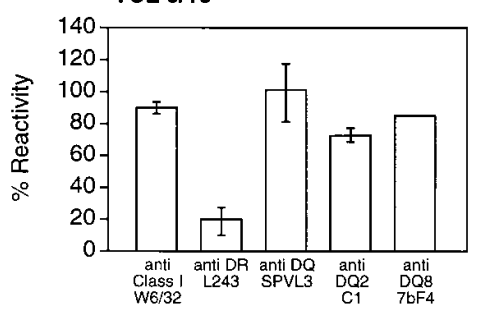

TCL 40

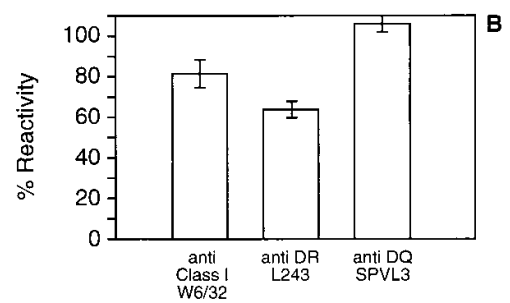

TCL 24/23

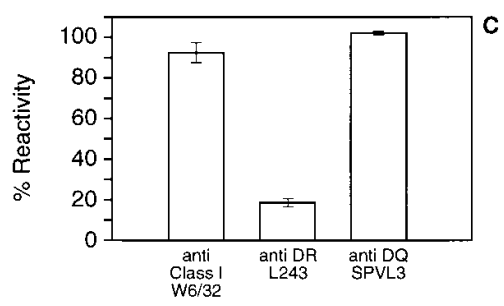

TCL 24/31

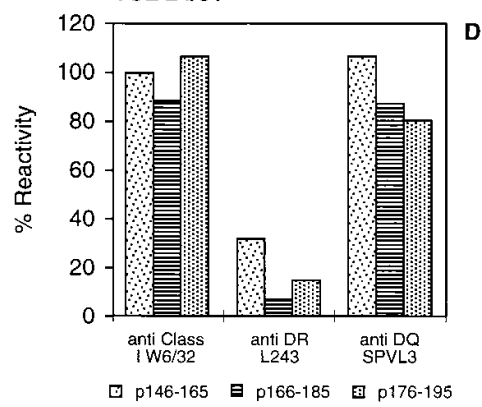

Figure 3. Inhibition of peptide presentation by mAbs directed against MHC class I and class II antigens. (A) Inhibition of the proliferative responses of the TCL isolated from patient 6 was studied with $\mathrm{mAb}$ recognizing either framework determinants on DR- (mAb L243) and DQ- (mAb SPVL3) heterodimers, or with $\mathrm{mAb}$ specifically recognizing the two DQ alleles (DQ2 and DQ8) of the autologous APC using $\mathrm{mAbs} \mathrm{C} 1$ and $7 \mathrm{bF} 4$, respectively. The class I-specific $\mathrm{mAb}$ W6/32 was used as a control. Proliferative responses of all TCL against p266-285 were substantially inhibited only by the DR-specific $\mathrm{mAb}$, whereas all DQ-specific $\mathrm{mAbs}$ as well as the class I-specific mAb caused no or only minimal inhibition. Percent reactivity was calculated as follows: $100 \times($ mean cpm of response to $\mathrm{p} 266-285$ in the presence of mAb minus mean cpm of response with medium containing only $\mathrm{mAb}) /($ mean $\mathrm{cpm}$ of response to $\mathrm{p} 266-285$ minus cpm of response with medium only). $100 \%$ reactivity is defined as the response to p266-285 minus the response of cells in medium alone. ( $B$ ) Inhibition of the proliferative response of TCL isolated from patient 40. Presentation of peptide p556-575 to TCL is significantly inhibited only by the DR-specific mAb L243. Inhibition of the proliferative response was studied with $\mathrm{mAb}$ recognizing framework determinants on DR- and DQ-heterodimers, or with a class I-specific mAb. $(C$ and $D)$ Presentation of p206-225 to TCL 24/23 and of the three peptides reactive with TCL $24 / 31$ is also only blocked by an anti-DR mAb.
DR2, DR6, and DR8 (2-6) (data not shown). Thus the DRB1*0401 allele exclusively determined the autologous restriction of presentation of peptide for these four TCL analyzed in detail. A fifth TCL (6/9) isolated from this patient showed a completely identical peptide specificity and restriction pattern. As is the case for the minimal epitope identified in patient 6 , the determinant identified in the DRB1*0401 homozygous patient 40 contained the basic motif for high-affinity binding to DRA, B1*0401 heterodimers in its central region: FRMVISNPA ([26, 27], see Fig. 6). We can conclude, therefore, that different patients carrying the high-risk-associated DR/Dw4 haplotype have $\mathrm{T}$ cells recognizing different GAD epitopes presented in the context of the DRA, B1*0401 molecule.

Investigation of the $T$ cell response profile in an IDDM patient expressing protective HLA-alleles. We next analyzed the

Table II. Identification of DRB1*0401 as the Restriction Element for Peptide p270-283

\begin{tabular}{|c|c|c|c|c|c|c|c|c|}
\hline \multirow[b]{2}{*}{ Donor } & \multicolumn{3}{|c|}{ Haplotypes of APC } & \multirow{2}{*}{$\begin{array}{l}\text { Matching for DR/DQ- } \\
\text { heterodimers }\end{array}$} & \multicolumn{4}{|c|}{ Proliferative responses against $\mathrm{p} 270-283(\mathrm{SI})^{\ddagger}$} \\
\hline & DRB1* & DQA1* & DQB1* & & TCL 6/4 & TCL 6/7 & TCL 6/8 & TCL 6/10 \\
\hline \multirow[t]{2}{*}{ KP 3} & 0301 & 0501 & 0201 & DR: 0 mismatch & 28.6 & 7.4 & 4.6 & 63.3 \\
\hline & 0401 & 0301 & 0302 & DQ: 0 mismatch & & & & \\
\hline \multirow[t]{2}{*}{ KP 71} & 0301 & 0501 & 0201 & DR: 0 mismatch & NT & 13.2 & 4.4 & 69.2 \\
\hline & 0401 & 0301 & 0301 & DQ: 1 mismatch & & & & \\
\hline \multirow[t]{2}{*}{$\mathrm{KP} 2$} & 1302 & 0102 & 0604 & DR: 1 mismatch & 42.1 & 9.6 & 4.9 & 61.1 \\
\hline & 0401 & 0301 & 0302 & DQ: 1 mismatch & & & & \\
\hline \multirow[t]{2}{*}{ KP 103} & 0301 & 0501 & 0201 & DR: 1 mismatch & 1.0 & $<1$ & 1.5 & 1.1 \\
\hline & 0404 & 0301 & 0302 & DQ: 0 mismatch & & & & \\
\hline
\end{tabular}

Allelic differences to autologous patient APC are given in bold. ${ }^{\ddagger}$ Data represent stimulation indices of one out of three independent experiments showing the same results. NT, not tested. 


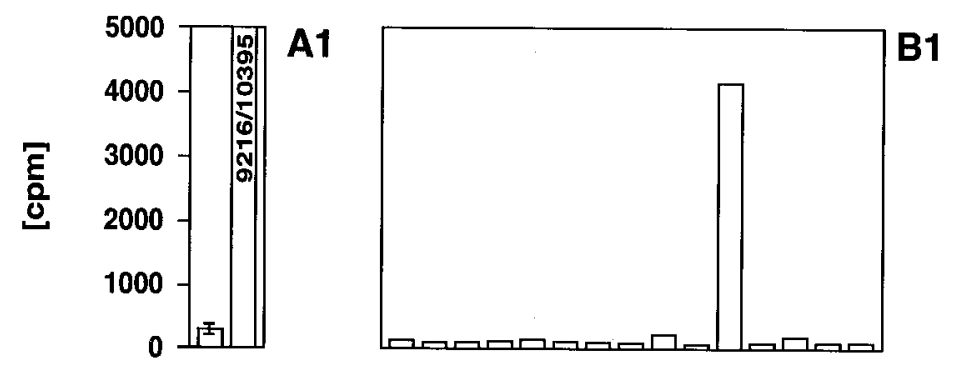

TCL 24/31
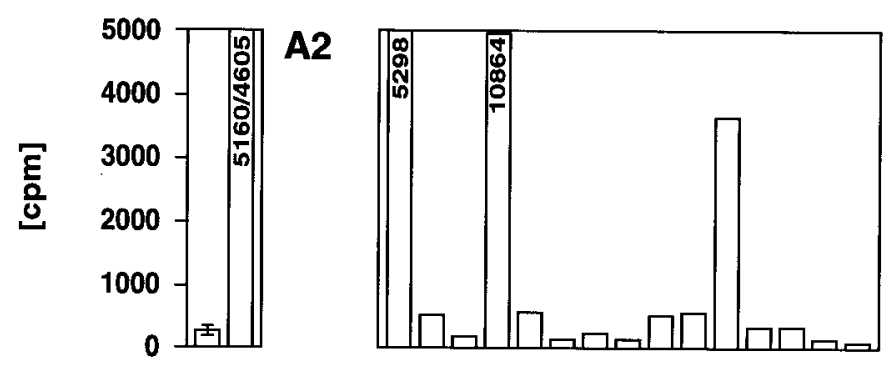

B2

TCL 24/32
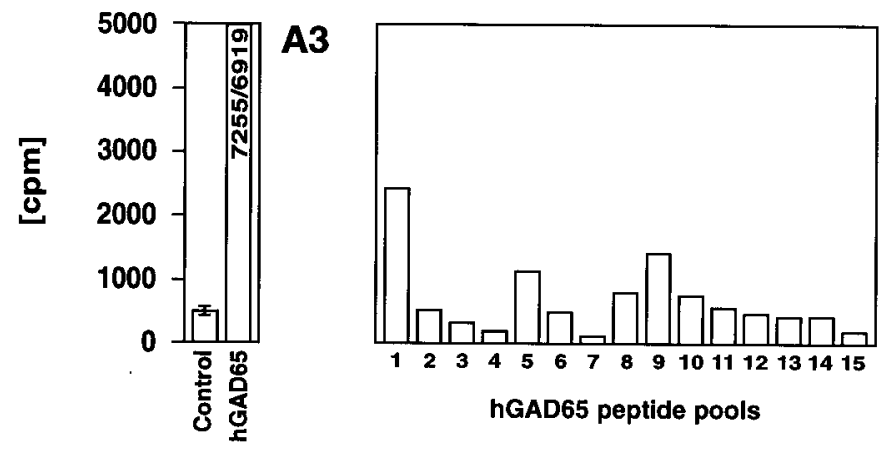

Figure 4. Proliferative responses of three independently isolated TCL from patient 24. (A1-B3) Proliferative responses against hGAD65 and peptide pools. (C1-C3) Proliferative responses against individual peptides included in pools 1, 4, and 11.

T cell response in a patient who was positive for DRB1*1501/ *1601 (Table I). Haplotypes carrying the DRB1*1501 allele are described to confer a protective effect, whereas individuals expressing a DRB $1 * 1601$ allele have a slightly increased risk for disease (8).

A set of three independently isolated TCL was obtained from this patient (Fig. 4, $A 1-A 3$ ). Screening the TCL with peptide pools revealed that the $\mathrm{T}$ cell responses in this patient were directed against a variety of peptides (Fig. 4, B1-C3). After the TCL were tested with individual peptides included in the reactive pools, four different reactive 20 mers were identified (Fig. 4, C1-C3). These included p146-165, p166-185, p176195 , and p206-225. Oligopeptide p166-185 was recognized by two independently isolated TCL. These four epitopes are located in close proximity to one another in the $\mathrm{NH}_{2}$-terminal half of the hGAD65 molecule.
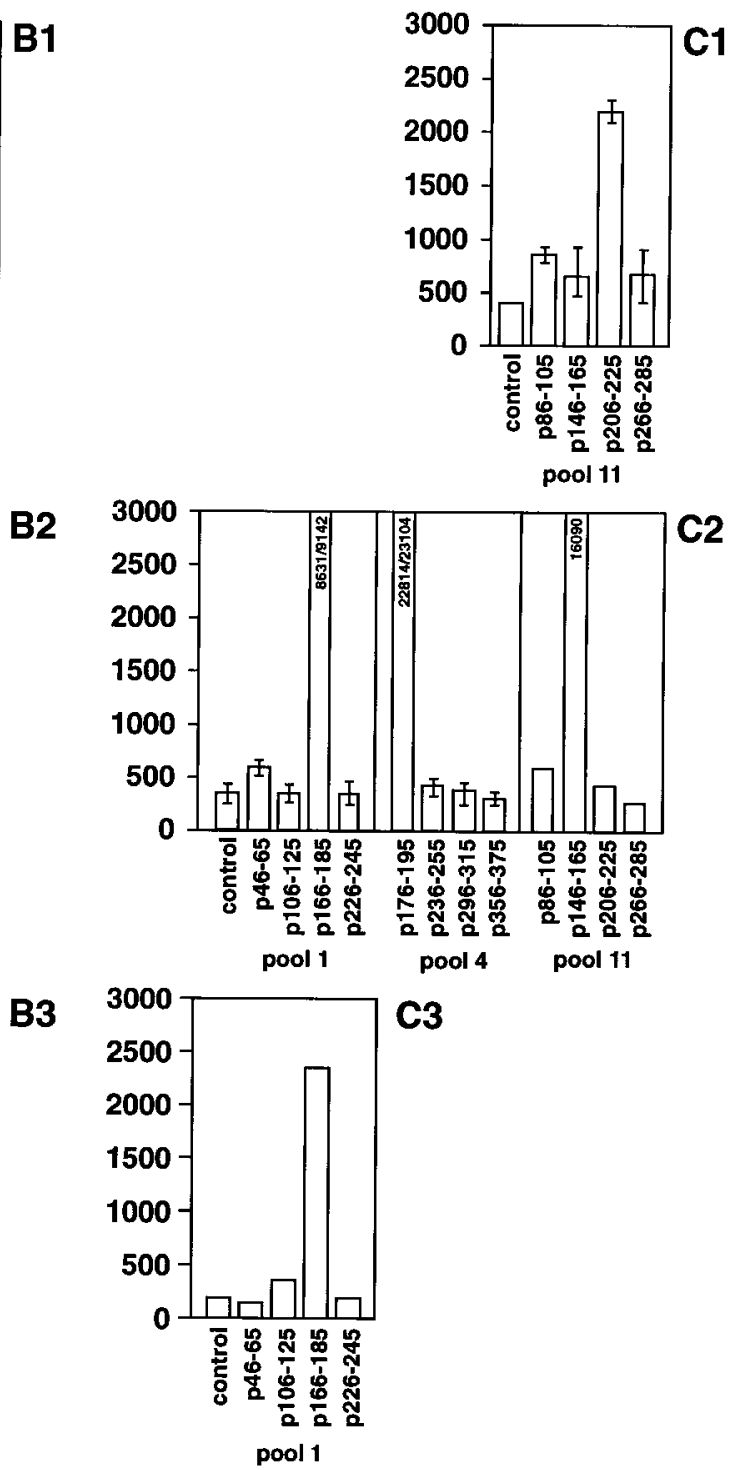


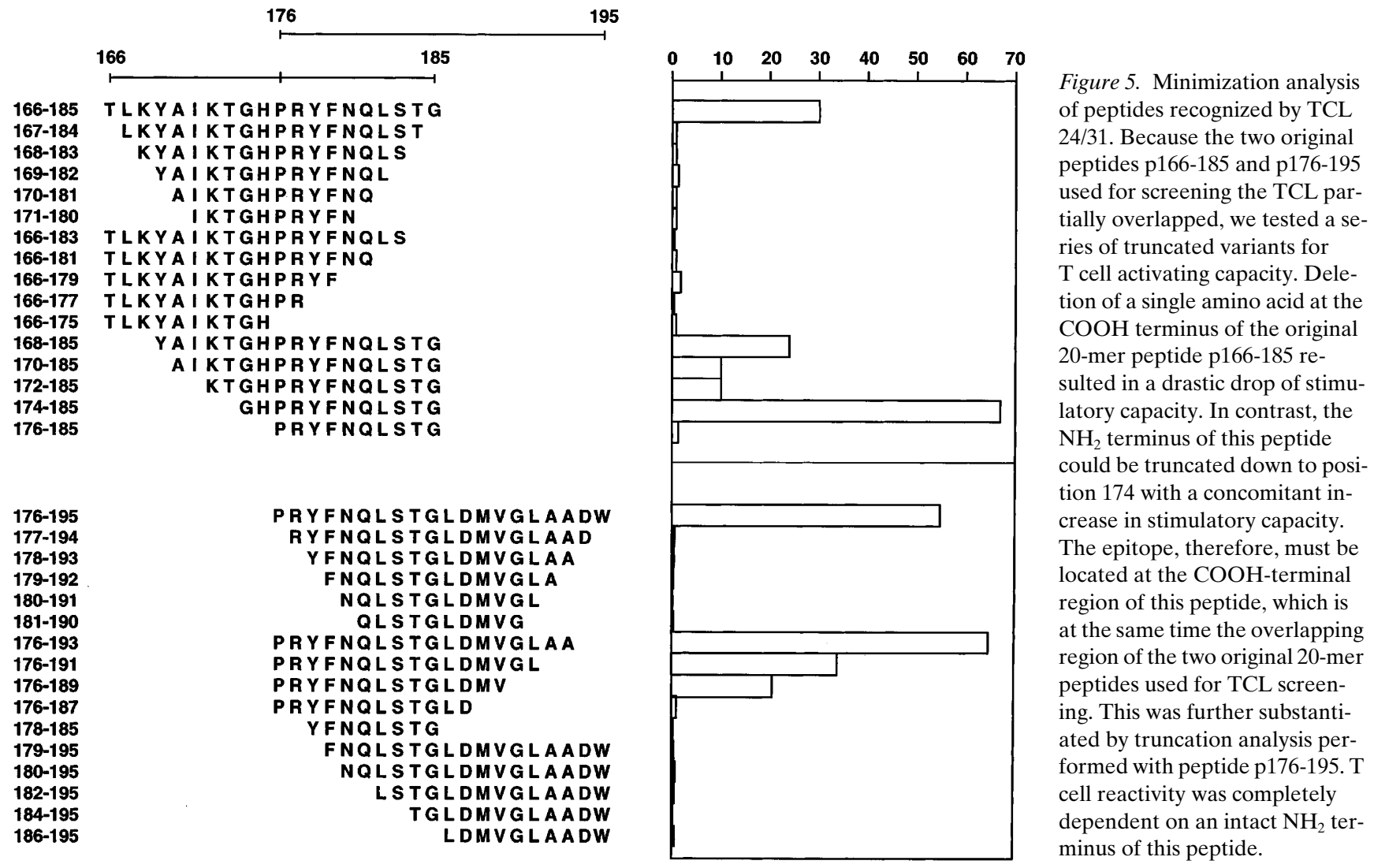

exhibits a high-affinity interaction with p174-185 and, in addition, has a minor cross-reactivity with p146-165.

Examination of the restriction elements used by TCL isolated from the patient with protective HLA-alleles. Antibodyblocking experiments indicated that all epitopes recognized by TCL isolated from patient 24 were presented by DR molecules (Fig. 3, $C$ and $D$ ). We tried to define in more detail the specific molecules used for presentation of the three autoreactive peptides recognized by patient 24 . Proliferation assays were performed using a panel of APC derived from donors who shared only one haplotype with this patient. Proliferation against the two epitopes recognized by TCL 24/31 was only induced when the APC shared the DRB1*1601 haplotype with the patient (Table III). In contrast, TCL 24/23 recognized the corresponding autoreactive peptide p206-225 only in association with the DRB1*1501 haplotype. Further identification of the restriction alleles by this approach was hindered by the close association of several other DR alleles coexpressed by this haplotype (DRB1, B5, B6).

Fig. 6 summarizes the position of the epitopes within the

Table III. Identification of the Restriction Elements for Peptide Presentation to TCL Isolated from Patient 24

\begin{tabular}{|c|c|c|c|c|c|c|c|c|}
\hline \multirow[b]{2}{*}{ Donor } & \multicolumn{3}{|c|}{ Haplotypes of APC } & \multirow[b]{2}{*}{$\begin{array}{l}\text { Matching for DR/DQ- } \\
\text { heterodimers }\end{array}$} & \multicolumn{4}{|c|}{ Proliferative responses (SI) against } \\
\hline & DRB1* & DQA1* & DQB1* & & & $\begin{array}{l}\text { TCL 24/31 } \\
\text { p146-165 }\end{array}$ & $\begin{array}{l}\text { TCL 24/31 } \\
\text { p176-195 }\end{array}$ & $\begin{array}{l}\text { TCL 24/23 } \\
\text { p206-225 }\end{array}$ \\
\hline \multirow[t]{2}{*}{ Pat 24} & 1501 & 0102 & 0602 & & Exp. 1 & 20.1 & 44.0 & 111.5 \\
\hline & 1601 & 0102 & 0502 & & Exp. 2 & 47.3 & 98.5 & \\
\hline \multirow[t]{2}{*}{ KP 109} & 1501 & 0102 & 0602 & DR: 1 mismatch & Exp. 1 & 1.0 & 1.0 & 121.3 \\
\hline & 0901 & 0301 & 0303 & DQ: 1 mismatch & Exp. 2 & 1.5 & 1.0 & \\
\hline \multirow[t]{2}{*}{ KP 35} & 1501 & 0102 & 0602 & DR: 1 mismatch & Exp. 1 & 1.8 & 0.9 & 24.4 \\
\hline & 0301 & 0501 & 0201 & DQ: 1 mismatch & Exp. 2 & 1.2 & 1.4 & \\
\hline \multirow[t]{2}{*}{ KP 41} & 1601 & 0102 & 0502 & DQ: 1 mismatch & Exp. 1 & 4.5 & 15.7 & 2.0 \\
\hline & 0101 & 0101 & 0501 & DR: 1 mismatch & Exp. 2 & 13.3 & 23.6 & \\
\hline \multirow[t]{2}{*}{ KP 17} & 1601 & 0102 & 0502 & DR: 1 mismatch & Exp. 1 & 7.1 & 10.8 & 2.1 \\
\hline & 1104 & 0501 & 0301 & DQ: 1 mismatch & Exp. 2 & 12.2 & 32.9 & \\
\hline
\end{tabular}

Allelic differences to autologous patient APC are given in bold. 
Figure 6. GAD65 epitopes recognized by TCL isolated from three recent onset IDDM patients. A panel of three independently isolated TCL from a DR*1501/1601 heterozygous patient recognized three epitopes, located in the $\mathrm{NH}_{2}$-terminal half of the hGAD65 molecule ( $\mathrm{p} 146-165$, p174-185, p206-225). Inhibition analysis and restriction studies performed with APC partially matched for particular DR and/or DQ alleles with the donor of these TCL revealed that p146-165 and p174-185 are recognized by one or several DR alleles expressed in the DRB1*1601 haplotype, whereas p206-225 is recognized in the context of one or several alleles of the DRB1*1501 haplotype. Five independently isolated TCL from a DR*0301/*0401 positive T cell donor all recognized the same epitope (p270-283) in the context of the DRB1*0401 heterodimer. This minimalized epitope is located in immediate proximity to the homology region duplicated in the Coxsackie virus P2-C protein, but does not overlap with it. A second DRB1*0401 associated epitope (p556-575) was identified in an IDDM patient, who was homozygous for this DR allele.

GAD65 sequence identified in this study, together with HLA class II alleles used for their presentation.

Analysis of cytokine production by GAD-specific TCL. TCL were stimulated by HLA-DR-matched APC that had been pulsed with the corresponding autoreactive peptides. After $72 \mathrm{~h}$ the supernatants were examined for cytokines, including IL-2, IL-4, IL-6, and IFNy (Table IV). With most TCL, IL-2 and IL-4 could not be detected, or were produced in very low amounts. One of the lines (TCL 40/2) expressed significant amounts of IL-6. All TCL examined secreted IFN $\gamma$ in response to the autoreactive peptides. Thus, the TCL are essentially of a TH 1-like phenotype, with IFN $\gamma$ being the dominant cytokine secreted (accompanied by a significant secretion of IL- 6 in one line).

\section{Discussion}

This report defines for the first time several naturally processed GAD65 epitopes that are recognized by long-term TCL isolated from PBL of recent onset IDDM patients. Although a number of previous attempts to identify $T$ cell reactive epitopes within GAD have used synthetic peptides to stimulate the PBL from patients $(12,13)$, we argue that this approach suffers from two major obstacles. First, the responses found in the majority of subjects are quite low. Second, we feel that this is not an ideal strategy for de novo epitope mapping because the arbitrary choice of start and stop positions in the peptides creates unnatural processing sites. Therefore, it remains to be

Table IV. Cytokine Production by GAD Specific T Cell Lines

\begin{tabular}{|c|c|c|c|c|c|c|c|}
\hline \multirow[b]{2}{*}{ TCL } & \multicolumn{2}{|c|}{ IL-2 pg/ml } & \multirow{2}{*}{$\begin{array}{c}\mathrm{IL}-4 \\
\mathrm{pg} / \mathrm{ml}\end{array}$} & \multicolumn{2}{|c|}{ IL-6 pg/ml } & \multicolumn{2}{|c|}{$\mathrm{IFN} \gamma \mathrm{pg} / \mathrm{ml}$} \\
\hline & Exp. 1 & Exp. 2 & & Exp. 1 & Exp. 2 & Exp. 1 & Exp. 2 \\
\hline $6 / 4$ & $<5$ & $<5$ & 40 & $<2$ & NT & 275 & 415 \\
\hline $6 / 8$ & $<5$ & $<5$ & $<20$ & $<2$ & NT & 55 & 140 \\
\hline $6 / 10$ & $<5$ & $<5$ & $<20$ & $<2$ & NT & 115 & 325 \\
\hline $24 / 23$ & 25 & 25 & 40 & $<2$ & $<2$ & 30 & 10 \\
\hline $40 / 2$ & $<5$ & $<5$ & $<20$ & 247 & 77 & 280 & 220 \\
\hline
\end{tabular}

1-2.5 $\times 10^{4} \mathrm{GAD}$-specific T cells were stimulated by irradiated APC in the presence of autoreactive peptides for $72 \mathrm{~h}$. Data are corrected for lymphokine amounts obtained by stimulation with medium only. $N T$, not tested. 
demonstrated that $\mathrm{T}$ cells induced by synthetic peptides are able to recognize naturally processed native GAD. In contrast, our approach is based on the initial isolation of hGAD65-specific TCL following priming with native protein. In a second step, these lines were analyzed with a set of overlapping peptides derived from the hGAD65 sequence, thereby allowing a detailed characterization of the molecular elements involved in antigen recognition. This method has been successfully applied to the study of the human autoimmune $\mathrm{T}$ cell repertoire in multiple sclerosis patients (16). Using this method, GADreactive TCL could be isolated from three new onset IDDM patients, whereas we failed to generate autoreactive $T$ cells using PBL from two normal donors who were completely or partially HLA class II matched. Although the number of individuals studied here is too limited to make general conclusions, our findings are in line with a recent report demonstrating with bulk culture assays that there is a higher incidence of GAD reactivity in recent onset IDDM patients, especially in prediabetics, as compared to normal controls (28). In addition, cytotoxic T lymphocytes specific for a GAD peptide could only be detected in the peripheral blood of subjects with recent onset IDDM and in prediabetics, but not in normal persons (14).

It should be noted that our patients are adults. Type I diabetes is heterogenous with respect to the age of disease onset and also with respect to progression. Our patients are of later onset-type, however the clinical criteria for IDDM (extensive weight loss, low body mass index, hyperketonuria, primary insulin dependency) were fulfilled. Two patients had hGAD65 antibodies together with islet cell antibodies. The patient who was autoantibody negative has a first degree relative with IDDM. Although our results are not likely representative of the early events of the disease, T cells reacting to GAD at the time of clinical diagnosis could represent a valid component of the process of beta cell killing associated with the development of hyperglycemia. It has been shown that at the time of onset, the pancreas contains islets in all stages of destruction (29), and the destructive process continues until all beta cells are destroyed (30).

The analysis of $\mathrm{T}$ cell response profiles in these three IDDM patients indicates that at the final stage of the disease two quite different patterns of $\mathrm{T}$ cell responses to GAD can exist: response can be confined to a single immunodominant epitope, as identified in a DRB $1 * 0301 / 0401$ heterozygous patient, or can be spread over three clustered autoreactive peptides, as found in a DRB1*1501/1601 positive donor. Furthermore, the same DRA, DRB1*0401 heterodimer was found to present two different epitopes in two different patients. Taken together, these data suggest that at the end point of a chronic disease like IDDM, the T cell response profiles can vary from an effector repertoire restricted to only a single epitope, to one with a rather broad autoimmune specificity based on recognition of multiple epitopes.

For maximum susceptibility to IDDM, certain alleles of both DRB1 and DQB1 loci are needed (4). DQ genes are more strongly associated with IDDM than are DR genes (2). DQ-associated susceptibility is determined by non-Asp amino acid residue 57 of the beta chain. The primary sequence of the amino terminal polymorphic domain is essential for $\mathrm{T}$ cell recognition. The murine equivalent of DRB is a null allele in NOD mice (31). Thus, when we started this study, we expected to find autoreactive $\mathrm{T}$ cells restricted to DQ alleles. Interestingly, we found that only $\mathrm{T}$ cells reactive with GAD-derived peptides in the context of DR heterodimers could be isolated from the periphery of type I diabetes patients. The two epitopes identified in two patients expressing the fully susceptible DRB1*0401 DQB1*0302 haplotype were found to be associated with the DRA, B1*0401 heterodimer. Their amino acid sequences fully comply with the structural requirements for high-affinity interaction with this heterodimer $(26,27)$. In addition, one of these two peptides (p270-283) is part of a 20 mer recently described to show high binding affinity to DRB1* 0401 (32). The second DRB1*0401 epitope (p556-575) has a nearly complete overlap with a 20 mer having the highest affinity to DRB1*0401 of all GAD65 peptides tested (32). Of particular interest is that one of our DRB1*0401-associated epitopes (p270-283) was also demonstrated to be the dominant naturally processed GAD65 $\mathrm{T}$ cell epitope in mice transgenic for human DRB1*0401 (32). These data, together with the low half-maximal stimulatory dose $(80 \mathrm{nM})$ of these two DRB1* 0401-restricted peptides, suggest that in these two patients, high-affinity epitopes are stimulating GAD-reactive $\mathrm{T}$ cells at the end stage of the disease.

Inhibition studies also clearly identified DR molecules as the restriction elements for the determinants recognized by a DRB1*1501/*1601-positive T cell donor. Using APC from donors sharing only one haplotype revealed that two autoreactive peptides were presented by the DR allele expressed in the susceptible haplotype with DRB1*1601, whereas one was presented via a DR allele encoded on the resistant haplotype with DRB1*1501. We do not believe that our culture conditions selected only for generation of DR-restricted TCL, since an essentially identical approach yielded DQ-restricted TCL from PBL of patients with multiple sclerosis (33). Rather, HLA-DR seems to be the dominant selecting element for autoreactive $\mathrm{T}$ cells active at the final stage of the disease, irrespective of whether this heterodimer is encoded by a susceptible or a resistant haplotype. We cannot, however, exclude a role of DQrestricted $\mathrm{T}$ cells being sequestered from the periphery, or appearing during earlier stages of the disease.

Since the human GAD65 sequence contains a region duplicated in the $\mathrm{P} 2-\mathrm{C}$ protein of Coxsackie virus, it has been speculated that a cellular response to the homologous viral sequence could induce $\mathrm{T}$ cell reactivity to GAD, and as a consequence, produce diabetes in humans (23). In addition, an elevated frequency of $\mathrm{T}$ cell responses, especially in HLA-DR4 positive patients, to a 20-mer GAD peptide (p260-279) encompassing the duplicated region, has been reported (12). Since one of the stimulatory 20-mer peptides (p266-285) identified in our study is partially overlapping with this fragment, we performed frame shift experiments and minimization analysis to identify the minimal stimulatory structure of this determinant. The results clearly demonstrated that the immunodominant epitope defined in this patient did not overlap with a six-amino acid stretch identical in GAD and the Coxsackie virus $\mathrm{P} 2-\mathrm{C}$ protein. It does, however, span a region of homology. As none of the other four determinants identified by our TCL have sequences in common with this duplicated region, we doubt that crossreactivity between this virus protein and GAD is essential to precipitate the clinical onset of insulin dependency.

The question remains whether the GAD-reactive $\mathrm{T}$ helper cells described in this study have $\beta$-islet cytotoxic potential. Investigation of the cytokines released after stimulation with the autoreactive peptides revealed that the TCL have a TH1-like cytokine pattern, with IFN $\gamma$ being the dominant cytokine re- 
leased. Expression of IFNy under the control of the insulin promoter in transgenic mice was shown to cause inflammation of the islets, and progression to diabetes (34). IFN $\gamma$ has biological effects on the insulin production of the beta cells (35). Given the important immunoregulatory role of IFN $\gamma$ for enhancing the cytolytic activity of natural killer cells and monocytes and macrophages, GAD-reactive $\mathrm{CD}^{+} \mathrm{T}$ cells that secrete this cytokine may have an important role in vivo by promoting the development of IDDM in genetically susceptible individuals.

The obvious diversity of $\mathrm{T}$ helper cell epitopes recognized by IDDM patients makes it unlikely that an epitope-specific immune intervention will be easily developed for IDDM. It is possible, however, that the initial response is directed against particular determinants, as is the case in the NOD mouse model (36). Investigation of the $\mathrm{T}$ cell response in different disease stages may resolve this issue, and perhaps allow a specific immunotherapy to be initiated at a stage when sufficient numbers of beta cells are still available to maintain metabolic homeostasis.

\section{Acknowledgments}

We thank Dr. E. Albert and Dr. E. Keller (Department of Pediatrics, University of Munich) for HLA-typing, and Daniela Geisenberger (Boehringer Mannheim Research Center, Penzberg) for excellent technical assistance.

Part of this work was supported by the Thyssen Foundation (R. Wank and D.J. Schendel).

\section{References}

1. Bottazzo, G.G., A. Florin-Christensen, and D. Doniach. 1974. Islet cell antibodies in diabetes mellitus with autoimmune polyendocrine deficiencies. Lancet. ii:1279-1282.

2. Todd, J.A., J.I. Bell, and H.O. McDevitt. 1987. HLA-DQ beta gene contributes to susceptibility and resistance to insulin-dependent diabetes mellitus. Nature (Lond.). 329:599-604.

3. Thomson, G., W.P. Robinson, M.K. Kuhner, S. Joe, M.J. Macdonald, J.L. Gottschall, J. Barbosa, S.S. Rich, J. Bertrams, M.P. Baur, et al. 1988. Genetic heterogeneity, modes of inheritance, and risk estimates for a joint study of Caucasians with insulin-dependent diabetes mellitus. Am. J. Hum. Genet. 43:799816.

4. Sheehy, M.J., S.J. Scharf, J.R. Rowe, M.H.N. Degimenez, L.M. Meske, H.A. Erlich, and B.S. Nepom. 1989. A diabetes-susceptible HLA haplotype is best defined by a combination of HLA-DR and HLA-DQ alleles. J. Clin. Invest. 83:830-835.

5. Nepom, G.T., and H. Erlich. 1991. MHC class-II molecules and autoimmunity. Annu. Rev. Immunol. 9:493-525.

6. Atkinson, M.A., and N.K. Maclaren. 1994. The pathogenesis of insulindependent diabetes mellitus. N. Engl. J. Med. 331:1428-1436.

7. Baekkeskov, S., M. Landin, J.K. Kristensen, S. Srikanta, G.J. Bruining, T. Mandrup-Poulsen, C. De Beaufort, J.S. Soeldner, and G. Eisenbarth. 1987. Antibodies to a $64,000 \mathrm{Mr}$ human islet cell antigen precede the clinical onset of insulin-dependent diabetes. J. Clin. Invest. 79:926-934.

8. Castano, L., and G.S. Eisenbarth. 1990. Type-I diabetes: a chronic autoimmune disease of human, mouse, and rat. Annu. Rev. Immunol. 8:647-679.

9. Atkinson, M.A., D.L. Kaufmann, L. Campbell, K.A. Gibbs, S.C. Shah, D.-F. Bu, M.G. Erlander, A.J. Tobin, and N.K. Maclaren. 1992. Response of peripheral-blood mononuclear cells to glutamate decarboxylase in insulindependent diabetes. Lancet. 339: 458-459.

10. Honeyman, M.C., D.S. Cram, and L.C. Harrison. 1993. Glutamic acid decarboxylase 67-reactive T cells: a marker of insulin-dependent diabetes. $J$. Exp. Med. 177:535-540.

11. Harrison, L.C., M.C. Honeyman, H.J. Deaizpurua, R.S. Schmidli, P.G. Colman, B.D. Tait, and D.S. Cram. 1993. Inverse relation between humoral and cellular immunity to glutamic acid decarboxylase in subjects at risk of insulindependent diabetes. Lancet. 341:1365-1369.

12. Atkinson, M.A., M.A. Bowman, L. Campbell, B.L. Darrow, D.L. Kaufman, and N.K. Maclaren. 1994. Cellular immunity to a determinant common to glutamate decarboxylase and Coxsackie virus in insulin-dependent diabetes. $J$.
Clin. Invest. 94:2125-2129.

13. Lohmann, T., R.D.G. Leslie, M. Hawa, M. Geysen, S. Rodda, and M. Londei. 1994. Immunodominant epitopes of glutamic acid decarboxylase 65 and 67 in insulin-dependent diabetes mellitus. Lancet. 343:1607-1608.

14. Panina-Bordignon, P., R. Lang, P.M. van Endert, E. Benazzi, A.M. Felix, R.M. Pastore, G.A. Spinas, and F. Sinigaglia. 1995. Cytotoxic T cells specific for glutamic acid decarboxylase in autoimmune diabetes. J. Exp. Med. 181: 1923-1927.

15. Wu, J.Y., L. Denner, C.T. Lin, and G. Song. 1985. L-Glutamate decarboxylase from brain. Methods Enzymol. 113:3-10.

16. Pette, M., K. Fujita, D. Wilkinson, D.M. Altmann, J. Trowsdale, G. Giegerich, A. Hinkkanen, J.T. Epplen, L. Kappos, and H. Wekerle. 1990. Myelin autoreactivity in multiple sclerosis: recognition of myelin basic protein in the context of HLA-DR2 products by T lymphocytes of multiple-sclerosis patients and healthy donors. Proc. Natl. Acad. Sci USA. 87:7968-7972.

17. Tsuji, K.-E., M.-E. Aizawa, and T.-E. Sasazuki. 1992. HLA 1991: Proceedings of the Eleventh Histocompatibility Workshop \& Conference. Oxford University Press, Oxford, UK. 419-426.

18. Johnson, J.P., H. Nordwig, and R. Wank. 1987. Epitope analysis with monoclonal antibodies directed against class II molecules subdivides HLADR2, DR3 and DR4: correlations with cellularly defined Dw specificities. Tissue Antigens. 29:26-33.

19. Roll, U., M.R. Christie, M. Füchtenbusch, M.A. Payton, C.J. Hawkes, and A.G. Ziegler. 1996. Perinatal autoimmunity in offspring of diabetic parents: the German multicenter 'BABY-DIAB' study. Detection of humoral immune responses to islet antigens in early childhood. Diabetes. 45:967-973.

20. Ogata, K., K. Ohta, H. Kubo, A. Yamaguchi, and H. Watanabe. 1995. The glutamic acid decarboxylase (GAD) antibodies and their clinical significance. Rinsho Byori. 43(5):468-471.

21. Bu, D.F., M.G. Erlander, B.C. Hitz, N.J.K. Tillakaratne, D.L. Kaufmann, C.B. Wagner-McPherson, G.A. Evans, and A.J. Tobin. 1992. Two human glutamate decarboxylases, 65-kDa GAD and 67-kDa GAD, are each encoded by a single gene. Proc. Natl. Acad. Sci. USA. 89:2115-2119.

22. Jenkins, O., J.D. Booth, P.D. Minor, and J.W. Almond. 1987. The complete nucleotide sequence of Coxsackie virus B4 and its comparison to other members of the picornaviridae. J. Gen. Virol. 68:1835-1848.

23. Kaufman, D.L., M.G. Erlander, M. Claresalzler, M.A. Atkinson, N.K Maclaren, and A.J. Tobin. 1992. Autoimmunity to two forms of glutamate-decarboxylase in insulin-dependent diabetes mellitus. J. Clin. Invest. 89:283-292.

24. Yoon, J.W., W.T. London, B.L. Curfman, R.L. Brown, and A.L. Notkins. 1986. Coxsackie virus-B4 produces transient diabetes in nonhuman-primates. Diabetes. 35:712-716.

25. Hou, J., C. Said, D. Franchi, P. Dockstader, and N.K. Chatterjee. 1994 Antibodies to glutamic acid decarboxylase and P2-C peptides in sera from Coxsackie virus B4-infected mice and IDDM patients. Diabetes. 43:1260-1266.

26. Hammer, J., E. Bono, F. Gallazzi, C. Belunis, Z. Nagy, and F. Sinigaglia. 1994. Precise prediction of major histocompatibility complex class II-peptide interaction based on peptide side chain scanning. J. Exp. Med. 180:2353-2358.

27. Rammensee, H.G., T. Friede, and S. Stevanovic. 1995. MHC ligands and peptide motifs-first listing. Immunogenetics. 41:178-228.

28. Durinivic-Bello, I., M. Hummel, and A.-G. Ziegler. 1996. Cellular immune response to diverse islet cell antigens in IDDM. Diabetes. 45:795-800.

29. Somoza, N., F. Vargas, C. Roura-Mir, M. Vives-Pi, M.T. FernandezFigueras, A. Ariza, R. Gomis, R. Bragado, M. Marti, D. Jaraquemada, and R. Pujol-Borrell. 1994. Pancreas in recent onset insulin-dependent diabetes mellitus. J. Immunol. 153:1360-1377.

30. Gorsuch, A.N., K.M. Spencer, J. Lister, J.M. McNally, B.M. Dean, G.F. Bottazzo, and A.G. Cudworth. 1991. The natural history of type-1 insulindependent diabetes mellitus: evidence for a long prediabetic period. Lancet. ii: 1363-1366.

31. Nishimoto, H., H. Kikutani, K. Yamamura, and T. Kishimoto. 1986. Prevention of autoimmune insulitis by expression of I-E molecules in NOD mice. Nature (Lond.). 328: 432-434.

32. Wicker, L.S., L. Chen, G.T. Nepom, J.F. Elliott, D.C. Freed, A. Bansal, S. Zheng, A. Herman, A. Lernmark, D.M. Zaller, et al. 1996. Naturally processed $\mathrm{T}$ cell epitopes from human glutamic acid decarboxylase identified using mice transgenic for the type 1 diabetes-associated human MHC class II allele, DRB1*0401. J. Clin. Invest. 98:2597-2603.

33. Wucherpfennig, K.W., and J.L. Strominger. 1995. Molecular mimicry in $\mathrm{T}$ cell-mediated autoimmunity: viral peptides activate human $\mathrm{T}$ cell clones specific for myelin basic protein. Cell. 80:695-705.

34. Saventnick, N., D. Liggitt, S.L. Pitts, S.E. Hansen, and T.A. Stewart. 1988. Insulin-dependent diabetes mellitus induced in transgenic mice by ectopic expression of class II MHC and interferon gamma. Cell. 52:773-782.

35. Campbell, I.L., A. Isarco, and L.C. Harrisson. 1988. IFN $\gamma$ and tumor necrosis factor $\alpha$ cytotoxicity to murine islets of Langerhans. J. Immunol. 141: 2325-2329.

36. Kaufman, D.L., M. Claresalzler, J.D. Tian, T. Forsthuber, G.S.P. Ting, P. Robinson, M.A. Atkinson, E.E. Sercarz, A.J. Tobin, and P.V. Lehmann. 1993. Spontaneous loss of T-cell tolerance to glutamic-acid decarboxylase in murine insulin-dependent diabetes. Nature (Lond.). 366:69-72. 